\title{
THE FINANCING OF LARGE-SCALE RENTAL HOUSING
}

\author{
J. W. Brabner SMITH*
}

In $193^{\circ}$ approximately $\$ 6,000,000,000$ of real estate mortgage bonds, issued to finance apartment buildings and other rental housing properties, were in the hands of the public. In fact, at this date, except for a comparatively few large insurance company loans, practically all such mortgage financing involving loans of $\$ 100,000$ or more was done by real estate bond houses such as S. W. Straus \& Company, ${ }^{1}$ Greenebaum Sons' Investment Company, and American Bond \& Mortgage 'Company. Many of these bond houses had enviable records over many years, when their business had been comparatively small and conservative. The growth and collapse of these bond houses is an interesting and instructive chapter in twentieth century financial history.

Before 1900 most of the financing of apartments and tenements was by savings banks and insurance companies. It is estimated that in 1913 the total volume of real estate bonds outstanding amounted to but $\$ 150,000,000$, and in 1921 it was only $\$ 500,000,000$. But the high yield of these bonds, generally always $6 \%$, the increasing demand for mortgage loans for large apartment buildings resulting from the rapid growth of our cities, and the success of the early issues of the mortgage bond houses, resulted in the belief among hundreds of thousands of small investors throughout the country that there was no security to compare with a "first mortgage gold bond."

The typical mortgage bond financing involved an issue of first mortgage bonds in denominations of $\$ 500$ and $\$ 1000$ bearing $6 \%$ interest, due in eight or ten years, the loan being partially amortized at a rate of five or ten per cent annually by calling the bonds by lot, with an occasional serial bond issue. The final payment of principal in the early issues was easily refinanced. Since there was no satisfactory depletion or depreciation fund provision, nor any requirement for retiring bonds when surplus earnings were large, owners were able to "milk" properties during the boom period. The bonds were secured by the property placed in trust with a corporate trustee, frequently a wholly owned subsidiary of the bond house, under a "trust" agreement

* Ph.B., LL.B., Yale University; J.S.D., Northwestern University. Membet of the Connecticut, Nen York and Illinois Bars. Lecturer on Real Property and Corporate Financing and Reorganization, Northwestern University Law School, r932-1933; Assistant Attorney General, Illinois, 1933; Special Assistant to the Attorney General of the United States, 1933-1935. Author of "The National Housing Program" (1936) 30 Illinois Law Review 557; "The Government's Housing Program to Date" (1936) 22 American Bar Ass'n lournal 631; "The National Housing Act Amendments of 1936 " (1938) 24 American Bar Ass'n lousnal 302; and other contributions to leyal periodicals.

This one company alone disposed of over one billion dollars of real estate bonds. 
which relieved the trustee from liability for failure to perform many ordinary trustee duties.

\section{The Collapse of the Bond Houses}

Unfortunately, most of these real estate bond houses passed from the hands of the conservative management which had built up their enviable records into the hands of a more speculative group, or had descended to children and grandchildren lacking the experience of the founders. The early success of the first mortgage real estate bond, resulting largely from the increase in demand for this type of housing, and the increase in value of urban real property, misled the younger generation into a false sense of security.

Gradually the demand of borrowers for money to finance apartment buildings grew less as the need for this type of housing was met, but the demand for mortgage bonds accelerated as investment funds were made increasingly available by the prosperous era of the 1920's. Instead of property owners seeking an investment house to finance an apartment building, the bond houses were seeking the property owner, showing him how a building could be financed without any capital on his part. Then a mortgage bond issue equal to the cost of building and property would be sold before the building was constructed. ${ }^{2}$

The amount of the bond issue had come to depend upon the "value" of the property securing the loan. The credit and ability of the owner of the property long since had been completely ignored. Frequently the mortgagor was a corporation with no other assets than the mortgaged property. In fact, the signatures on millions of dollars of mortgage bonds were those of clerks, stenographers, or other "dummies," with no capital and with no experience whatsoever in property management. Now even the valuation was unsound. Property appraisals more and more indicated fictitious valuations based, not on actual cost, but on a highly speculative estimate of prospective high rental and occupancy. Too late the courts and the holders of real estate bonds became aware that "the valuation of the security should be based on physical, tangible property, and not on some unsubstantial, fanciful, or ephemeral intangible." ${ }^{3}$ The Blue Sky Acts, such as those in Illinois, did not exempt from requirements of detailed appraisals and reports real estate bond issues if the aggregate amount of bonds issued exceeded $80 \%$ of the fair market value of the property, but state officials failed to question whether or not the bond issues met this qualification.

The inevitable result was that, even while the great era of prosperity was at its height, bond issues were going into default. Bond houses, such as F. H. Smith Company and G. L. Miller \& Company, which financed many large apartments and

\footnotetext{
'So great was the public demand for real estate bonds that the bond houses even went to the extent of promoting, indirectly, athletic and social clubs in large cities for the purpose of financing luxurious club buildings through the sale of bonds to the public.

"People v. F. H. Smith Co., 230 App. Div. 268, 243 N. Y. Supp. 446 (1930). The court went on to ayy, "Undoubtedly, it would be proper, and in some cases advisable, to check this valuation against prospeetive rentals of the property, capitalized at a fair rate for similar properties. But standing alone, the latter appraisal is not a proper basis for a conservative loan." See also Carey and Brabner-Smith, Studies in Realty Mortgage Foreclosures: Pt. IV, Reorganizations (1933) 27 ILL. L. REv. 849.
} 
hotels in the East and South, failed dismally and notoriously. Many issues of other houses were going into default, but the bond houses frequently advanced interest payments from their own funds, in order to deceive the public and continue to sell more bonds. When the stock market finally collapsed and credit was tightened, bond issues were allowed to default to such an extent that it is doubtful if $5 \%$ weathered the storm of foreclosures, receiverships, protective committees, and reorganizations.

\section{The End of Real Estate Bond Issue Financing}

At this stage many of the bond houses might have redeemed themselves by using all their efforts to protect the holders of mortgage bonds which they had sold. However, with very few exceptions, those in control of real estate bond houses made every endeavor to protect themselves at the expense of the bondholders. "Protective" committees for the bondholders were formed, but control rested with the management of the bond house, thus preventing possible claims and legal proceedings of bondholders against them. Through this control, moreover, management of the foreclosed properties was obtained, and business patronage resulting therefrom was directed to them and to their friends. Inside information as to the value of the various real estate bond issues was used for the purpose of trading in the securities. In some instances false markets were created for the bonds, thus enabling the accumulation of bonds at prices far below their value even under receivership. ${ }^{4}$

The situation was not helped by the fact that the bonds were generally secured by property placed in trust with corporate trustees. Almost invariably the corporate trustee took the position that it owed no active duty to protect the bondholders. In fact the trustee very frequently followed the same path as the bond house-it made what it could out of receiverships, depositary fees, and property management, while the bondholders were completely demoralized.5

While trustees and protective committees were foreclosing and obtaining receiverships, insurance companies and other mortgagees which had loaned money on similar types of rental dwellings were working out agreements with property owners to prevent foreclosure and to obtain as much income as possible during the depression, with the result that in most cases those loans have come through the depression with the principal intact even if interest rates have been cut in half. This experience accentuated the unhappy results of bond issue financing, for most of the billions of dollars of real estate bonds have paid no interest throughout the past five or six years, and the principal investment has in most cases suffered some depreciation, due to mismanagement of properties and expenses of foreclosures, receiverships, protective committees, and reorganization.

The inevitable result is that a new generation of investors must be born before real estate mortgage bonds can be successfully offered to the public.

'See S. E. C., Report on the Sudy and Investigation of the Work', Activities, Personnel and Functions of Protective and Reorganization Committees, especially Pt. 3 (1936), "Committees for the Holders of Real Estate Bonds"; Carcy and Brabner-Smith, Stzudies in Realty Mortgage Foreclosures: Pt. III. Receiverships (1933) 27 ILL. L. REv. 717, Pt. IV. Reorganization, id. 849.

${ }^{5}$ See S. E. C., op. cit. supra note 4 , Pt. 3 . 
The Need for Rental Housing Today

As the result of changing economic and social conditions, an increasingly large part of our population, whether through necessity or choice, is renting dwelling accommodations. In 1930 about $56 \%$ of all urban families in the United States occupied rental dwellings. Due to the depression, which forced many families to dispose of their homes, the proportion is even greater today. At the same time, except for efforts on the part of the federal, government through the Housing Division of the PWA and, more recently, the United States Housing Authority, to furnish adequate housing for people of very low income, and the private rental housing projects stimulated through loans insured by the Federal Housing Administrator under Sections 207 and 210 of the National Housing Act, there has been practically no rental housing construction since $193^{\circ}$.

Moreover, so inferior was the type and quality and so bad the location of many apartment dwellings constructed during the "boom" period, that they are already untenantable. A further stimulus for the demand comes from a growing realization on the part of the public that rental housing for moderate income groups is profitable if built on an extensive scale, with modern design, construction and equipment, and with broad landscaped areas to prevent adverse encroachments. ${ }^{b}$ We are entering an era when, for the first time, home rental is being made attractive through landlordism imbued with constructive investment motives and property management trained to anticipate the needs and meet the desires of tenants. ${ }^{7}$

\section{Federal Housing Administration Insurance of Loans on Housing Projects}

As a result of the failure of bond houses, the loss of confidence of investors in mortgage bonds, the timidity of banks and other investing institutions to loan money except upon terms too onerous for borrowers, the lack of private equity capital to finance rental housing (caused by the depression), and the disastrous results of the unsound speculative era of building, the construction of large scale rental housing was at a standstill while business generally was emerging from the depression. The National Housing Act was passed on June $27,1934,{ }^{8}$ a major objective being to stimulate the construction industry principally through a form of guarantee to lending institutions of the credit of the citizen who wished to borrow money to repair and improve his real property or to acquire a home. ${ }^{9}$

The subject of government housing projects for low-income groups as a method of stimulating business was commencing to receive consideration at this time, and Section 207 was inserted in the National Housing Act without much discussion but with the hope that something might also be accomplished in this field. This section provided that the Administrator could insure loans secured by property "held by Federal or State instrumentalities, private limited dividend corporations, or municipal

\footnotetext{
- See Marsh, Private Low-rent Housing Can Succeed, Insured Mrge. Portfolio, March, I938.

${ }^{7}$ See Lewis, Rental Housing, Coming New Industry, Insured Mrge. Portfolio, Jaa., 1938.

${ }_{4}^{8} 8$ STat. 1246 (1934), I2 U. S. C. A. c. 13.

- See Wallace, Strvey of Federal Legislation Affecting Private Home Financing Since 1932, supra, at
} p. 499. 
corporate instrumentalities of one or more States, formed for the purpose of providing housing for persons of low income which are regulated or restricted by law or by the Administrator as to rents, charges, capital structure, rate of return, or methods of operation." The only other restrictions of this section were to empower the Administrator to designate terms, conditions and provisions of the mortgage loans, to impose a premium charge in his discretion, and to limit the insurance to projects not exceeding $\$ 10,000,000$. This section of necessity was interpreted as an effort to facilitate the provision of adequate rental housing for persons of moderate income, and not an excursion into the field of housing for people whose income without government subsidy is insufficient to give a fair return to private capital. ${ }^{10}$

The first loan insured under this section was made to a Virginia corporation organized by a builder who placed in the corporation a tract of land near Washington, D. C., where the great increase in population at this time was causing a tremendous demand for rental housing for moderate and low-income families. The corporate charter contained certain protective provisions requested by the Federal Housing Administrator, including a provision limiting annual dividends. The loan, for $\$ 875,000$, made by a leading New York life insurance company, was approved for insurance in April, r935, after a careful scrutiny and occasional change of plans and specifications to assure that the project would be economically sound. Proceeds of the loan were advanced as construction progressed. The project of 276 apartments was ready for occupancy in September, I935. As with all succeeding loans of this nature, the mortgagor makes but one fixed periodic payment, generally a monthly payment to the mortgagee, which covers interest, principal amortization, hazard insurance, mortgage insurance premiums, and estimated taxes.

As other applications for loans were submitted and approved and projects were constructed, experience resulted in formation of settled policies. Practically all applicants for insured loans contemplated the organization of a corporation under the ordinary business corporation laws of the state where the property was located, so that the Administrator was obliged to regulate such corporations. A. form of corporate charter was adopted pursuant to which the Administrator may designate one director of the corporation and is the holder of stock, nominal in amount, but of a special class, entitling him to designate all but one member of the board upon default in required payments under the insured mortgage loan. ${ }^{11}$ Stock dividends

\footnotetext{
${ }^{10}$ See Greer, Applying the New Large Scale Housing Program, Insured MTae. PortFouto, April, 1938.

in Mortgage and forcelosure laws designed to protect the farmer subject to the vagaries of nature (such as the one-year redemption period), and the home owner affected by unforeseeable economic conditions and personal misfortunes (the right of possession after default, moratoria laws, etc.) are, without reason or justice, applicable as well to mortgages and deeds of trust en large housing properties, which are purely commercial ventures. If the mortgagee seeks protcction by insuring the thortgage against default, the insurer in this case is entitled to the privilege of controlling the management as soon as the mortgagor fails to live up to the terms of the loan agreement, and should not have to wait for a court to determine whether this is "equitable." The representation of the Federal Housing Administration on the board of directors enables the Administrator to keep in constant and direct contact with the management while the mortgage is in good standing, so that he is in a position to know whether the default is due to incompetent management or to other causes.
} 
(not profits, as occasionally believed) are limited generally to $6 \%$ or under, although they may attain $8 \%$ after certain additional reserves are accumulated.

A cash working fund must be available before dividends may be declared, and the corporation must set up a reserve for replacements and a general reserve. The purpose of the reserve for replacements is to build up a fund sufficient to replace fixtures and equipment as needs arise. It is an annual charge based upon the estimated life of the actual fixtures and equipment in each project. Although in the nature of a depreciation charge, it is funded, and the funds must be invested in specified classes of liquid securities, or, by mutual agreement, applied to debt retirement.

The purpose of the general reserve is to build up a fund which will be available in years when the project may have financial difficulties. In general, a sum equivalent to one per cent of the amount of the mortgage loan must be set aside until the reserve is equal to one half of the total annual payment due under the amortized mortgage loan (about $3 \frac{1 / 2}{2} \%$ of the mortgage loan). The fund must be invested in the same way as the fund for replacements.

Other new features of this form of large-scale housing financing are as follows:

I. The loan must be completely amortized through the regular monthly or quarterly payments.

2. The interest rate is limited to a maximum of $4 \frac{1}{2} \%$, with an additional amount of approximately $1 / 2 \%$ for the annual mortgage insurance premium.

3. A long amortization period, up to twenty-seven years, and longer in the case of fireproof construction, is provided, so that the fixed periodic payments are not excessive.

4. The mortgagor's payments automatically will tend to adjust themselves to cyclical economic trends, although the level annuity payment method is used (a fixed periodic payment covering both principal and interest, which results in increasing principal payments as interest payments decrease due to amortization of principal).

5. There can be no "milking" of the property because of the limited dividend provision. If occupancy or rentals are higher than anticipated in certain years, surplus earnings will be applied to further amortization.

6. Sponsors of the project must have a substantial equity in the property, fixed at $20 \%$ or more of the appraised value thereof. As the debt is retired and equity increases, the mortgagor's interest in protecting this equity will not lag.

7. There must be a substantial cash fund, based on the probable needs of each project, to meet all possible expenses during the first days of operation of the project.

8. The sponsors must furnish proof of managerial ability. After the project is completed the Federal Housing Administrator will continue to gain knowledge of the ability of the management, not only through his representative on the board of directors of the mortgagor, but by means of an annual certified audit, and monthly occupancy figures.

9. There is a statutory provision that the project must be "economically sound," as in the case of ordinary insured mortgage loans. The Administrator takes particular 
pains to meet this requirement, and a careful investigation is made of the neighborhood, the proposed rentals, availability of tenants, the type and soundness of construction of the proposed building or buildings, the fitness of dwelling accommodations, and future prospects, such as the stability of employment for potential tenantry, neighborhood protection and transportation facilities.

\section{Amendments to Section 207 of National Housing Act}

By the middle of 1937 over 300 projects capitalized at approximately $\$ 700,000,000$ had been submitted for insurance and $\eta^{\mathrm{I}}$ of these had been approved for insurance, but only 32 were on the active list. These 32 projects involved mortgages of $\$ 26$,000,000 and xrould house 7,600 families. Practically all loans came through a few large insurance companies. (It appeared that financing through bond issues was practically impossible even when the loan was thus insured.) The projects completed were highly successful but, while the public was being educated, large-scale rental housing was still a minor factor in promoting building construction, for there was little other building of this nature in spite of the demand. Therefore, certain changes were suggested to the Congress convening in January, 1938, and shortly thereafter these changes were, in substance, enacted. ${ }^{12}$

The important amendments of 1938 to the National Housing Act should greatly stimulate rental housing projects. Under the original Act, the mortgagee received the benefits of insurance (debentures of the Administrator guaranteed by the United States covering principal and certain advances made by the mortgagee) only upon acquisition of the property through foreclosure or otherwise, and conveyance of it to the Administrator. Now, upon default by the mortgagor in the case of mortgages insured under Section 207, the mortgagee has the option of assigning the mortgage directly to the Administrator and receiving the guaranteed debentures, merely paying a charge equal to $2 \%$ of the principal outstanding amount of the mortgage (an amount which is deducted from the face amount of the debentures)..$^{13}$ Moreover, the Administrator no longer need hesitate about insuring a loan for fear that the project might not properly be considered to be "for persons of low income." The only limitation of Section 207 of the present Act in this respect is that the loan may not exceed $\$ 1,35^{\circ}$ per room. By the end of July, 1938, r 39 projects designed to accommodate over 19,000 families and valued at nearly $\$ 100,000,000$ were on the FHA active list, 21 of which are completed and in operation.

\section{National Mortgage Associatrons}

Congress has provided an instrumentality through which funds can be obtained from the public, -national mortgage associations ${ }^{14}$-and the success of the first such

${ }^{22} 52$ STAT. 8 (1938), 12 U. S. C. A. (Supp. 1938) c. 13.

${ }^{23}$ This $2 \%$, as well as other sums due the mortgagee from the mortgagor as a result of the foreclosure proceedings which are not included in the amount of the debentures, are included in the certificate of claim. This certificate, issued by the Administrator to the mortgagee, is paid off to the extent that the net proceeds from the liquidation of the property exced the face amount of the debenturcs.

"See Wallace, Sturvey of Federal Legislation Affecting Private Home Financing Since 1932, supra, p. 506, for a bricf description of Title III of the National Housing Act, which provides for National Mortgage Associations. 
association to be formed, the Federal National Mortgage Association, probably foretells the source of funds for most of our private rental housing in the next decade. It is an association which makes its profit on the difference between the cost of mortgage loans which it makes or buys, and the interest which it pays on the obligations which it sells to the public to obtain funds.

Since the obligations are issued only against at least an equal amount of insured loans, since even in the event of default of all home and rental-housing mortgage loans the association would receive government-guaranteed debentures practically equal in amount to the principal of the defaulted mortgages, and since there is an additional cushion of capital equal to at least $5 \%$ of outstanding bonds, it is natural that these securities are regarded with favor. The oversubscription of the first issue indicates that one billion dollars of such obligations could be marketed over a comparatively short period without any great increase in interest rates. Statutes in many states have already been enacted making national mortgage association obligations legal investments for various investing institutions and for public, semi-public and trust funds. ${ }^{15}$

The Federal National Mortgage Association was organized as follows: On February 9, 1938, the Federal Housing Administration issued special "Regulations for National Mortgage Associations Controlled or Operated by the United States or any Agency thereof." Pursuant to these regulations an application was filed for authority to establish an association of $\$ 10,000,000$ capital, the stock to be $\$ 100$ par value and to be subscribed for at \$IIo per share, thus setting up a surplus for operations of $\$ 1,000,000$. Four of the five prospective incorporators signing the application were officers of the RFC, the fifth being a prominent Washington banker. With the application there was transmitted a draft of Articles of Association upon a form approved by the Administrator. ${ }^{16}$

On February 10, 1938, the Administrator issued a Certificate of Approval, authorizing the prospective incorporators to organize the association. On April II the Association applied for authority to transact business and furnished the Administrator with a Certificate of Organization setting forth that the entire capital stock was subscribed and paid for by the RFC. To this certificate was attached certified copies of minutes of the organization meetings of the stockholders and of the board of directors. The Administrator then issued a certificate authorizing the Association to transact its business.

On April 15, the Federal National Mortgage Association issued a circular concerning its activities; pointing out that, unlike privately owned national mortgage associations, it is empowered to make direct loans only on rental housing projects, apartment buildings and group houses securing loans insured under Section 207 or

\footnotetext{
${ }^{25}$ See Margraf, Laws Relating to the Investment of Trust Funds, 1930-1937 (1938) 5 LAw \& Contexp. Pros. 399, 403-404.

${ }^{20}$ The Articles set forth the name of the proposed association, the location of its principal office, which is in Washington, D. C., the names and addresses of the directors, a statement of its powers, and the powers of its officers and directors, and information with respect to the.capital stock to be issued.
} 
Section 210 of the National Housing Act. Conditions of such loans were set forth, including an initial service charge of $1 \frac{1}{2} \%$ to $2 \%$ if funds are to be disbursed as construction progresses. The Association stated further that it would purchase mortgages of this class and also home mortgages insured under Section 203, if secured by newly constructed property. The seller must continue to service the mortgage but will be paid a servicing fee.

On May Ir, the Federal National Mortgage Association, through the RFC, invited subscriptions for about $\$ 25,000,000$ of $2 \% 5$-year notes at par. ${ }^{17}$ The issue was oversubscribed fifty times (this is said to be one of the largest oversubscriptions for any governmental issue in the history of this country), and approximately $\$ 30,000,000$ of notes were issued. The notes were soon quoted at approximately $101 \frac{1}{2}$, which is the present market price. In connection with this issue the Association announced it would publish semi-annual statements of profit and loss and of condition, including a classification of mortgages held and the status thereof.

\section{Insured Lonns on Small Housing Projects}

It became evident in 1937 that the procedure for obtaining insured loans under Section 207 of the National Housing Act was too elaborate for use with smaller multi-family developments. As a practical matter there was no provision for insuring loans from the $\$ 16,000$ group up to approximately the $\$ 200,000$ class. As a result a new section, Section 2ro, was added by the 1938 amendments. ${ }^{18}$ This section provided for the insurance of mortgages of from $\$ 16,000$ to $\$ 200,000$ if secured by a group of not less than ten single family dwellings or one or more multi-family dwellings. Although release clauses may be included in such a mortgage so that individual houses may be sold off, its primary purpose is for properties built to be rented. Other distinctions from Section 207 are that the mortgagor need not be a corporation, and, if it is, the corporation is not regulated or restricted by the Administration. The amortization period is limited to twenty-one years, the maximum mortgage amount per room permitted is $\$ 1,150$, and the interest rate may be as much as $5 \%$. In order to obtain the benefits of insurance, the mortgagee, upon default, must acquire the property and turn it over to the Administrator, as in the case of insured loans upon homes. ${ }^{19}$ It is probable that most of the smaller apartment houses erected in the next few years will be financed by such loans made by national mortgage associations and savings banks, insurance companies, and other investing institutions.

\footnotetext{
${ }^{27}$ These notes are redeemable at the option of the Association at a fraction over par on any interest payment date and redcemable at the option of the bolder if the RFC disposes of a controlling interest in the capital stock of the Association to private sources. The Association covenants to hold insured mortgages which are not in default for more than 90 days or cash or government securities at least equal to the aggregate amount of outstanding notes and other indebtedness. Notes are payable at the option of the holder if a breach of this covenant continues for 90 days. The Association is permitted to use amortization payments on mortgages owned by it for the redemption of outstanding obligations.

${ }^{28} 52$ StAт. 22, 12 U. S. C. A. (Supp. 1938) \$1715a.

${ }^{20}$ See Greer, Applying the New Large Scale Housing Program, Insured Mtce. Porrfouro, April, $x 938$.
} 